\title{
Experimental Neonatal Group B Streptococcal Pneumonia: Effect of a Modified Porcine Surfactant on Bacterial Proliferation in Ventilated Near-Term Rabbits
}

\author{
EGBERT HERTING, CONNIE JARSTRAND, OMID RASOOL, TORE CURSTEDT, \\ BO SUN, AND BENGT ROBERTSON \\ Research Unit for Experimental Perinatal Pathology, Karolinska Hospital [E.H., B.S., B.R.]; \\ Department of Clinical Bacteriology, Huddinge Hospital [C.J., O.R.]; and Department of \\ Clinical Chemistry, Danderyd Hospital [T.C.], Stockholm, Sweden
}

\section{ABSTRACT}

We studied bacterial proliferation in relation to surfactant treatment in a model of neonatal group B streptococcal (GBS) pneumonia. Surfactant (Curosurf) was isolated from pig lungs with a method preserving only polar lipids and hydrophobic proteins. Near-term rabbit fetuses were ventilated in a body plethysmograph system. At $15 \mathrm{~min}$, a suspension of GBS strain $090 \mathrm{Ia} \mathrm{LD}(5 \mathrm{~mL} / \mathrm{kg}$, concentration $\sim 10^{9} / \mathrm{mL}$ ) was instilled intratracheally. At $30 \mathrm{~min}$, surfactant $(n=12)$ or sterile saline $(n=13)$ was administered via the airways $(2.5 \mathrm{~mL} / \mathrm{kg})$. A control group $(n=12)$ received the same volumes of saline. After $5 \mathrm{~h}$ the animals were killed, and samples for blood cultures and blood gases were taken from the heart. The left lung was aseptically removed, weighed, homogenized, serially diluted, and cultured on blood agar plates. The results were expressed as mean $\log _{10}$ colony forming units/g lung \pm SD. Compared with animals $(n=12)$ killed immediately after GBS instillation $(8.13 \pm 0.54)$, there was a significant increase in bacterial numbers in both groups ventilated for $5 \mathrm{~h}$, but values for surfactant-treated animals $(8.96 \pm 0.38)$ were lower than those for animals receiving saline $(9.46 \pm 0.50$; $p<0.05$ ). After $5 \mathrm{~h}, 96 \%$ of GBS-infected animals had positive blood cultures. Light microscopic examination of the right lung of GBS-infected animals revealed inflammatory changes that tended to be less prominent in surfactanttreated rabbits. We conclude that intratracheal inoculation of near-term rabbits with GBS resulted in a significant bacterial proliferation during $5 \mathrm{~h}$ of ventilation and that bacterial growth was mitigated by treatment with surfactant. (Pediatr Res 36: 784-791, 1994)
CFU, colony forming unit
Abbreviations
GBS, group B streptococcus
RDS, respiratory distress syndrome

GBS is a frequently encountered pathogen in the neonatal period (1). Vaginal colonization with GBS is commonly found in pregnant women. Vertical transmission occurs in approximately $40 \%$ of deliveries, but only approximately $1 \%$ of neonates born to these mothers develop clinical signs of GBS infection (2). If diagnosis and treatment are delayed, the condition has a substantial mortality, especially in premature infants (2). Susceptibility to GBS infections depends on host defense factors (e.g. lack of type-specific opsonizing antibodies) and

Received January 26, 1994; accepted June 21, 1994.

Correspondence: Bengt Robertson, M.D., Research Unit for Experimental Perinatal Pathology, Department of Pathology, L1/01, Karolinska Hospital, S-171 76 Stockholm, Sweden.

Supported by grants from the Deutsche Forschungsgemeinschaft (DFG $\mathrm{He}$ 2072-1/2), the Swedish Medical Research Council (Project 3351), Oscar II:s Jubileumsfond, and the Research Funds of the Karolinska Institute. virulence factors (e.g. polysaccharide capsule) of the infecting microorganism (3-6).

Animal models using rabbits, mice, and rats have been used for studies of experimental neonatal GBS infections (7-9). In these studies, the animals were either infected by injection $(7,9)$ or a bacterial suspension was nebulized via the airways in spontaneously breathing animals $(8,9)$. Our intention was to develop a model of GBS pneumonia in ventilated newborn rabbits infected by intratracheal injection of a bacterial suspension.

RDS and GBS pneumonia are difficult to differentiate on clinical grounds (10), and therefore neonates with GBS pneumonia might receive surfactant therapy. In a recent "rescue" study (11), about $10 \%$ of infants with a clinical diagnosis of RDS treated with surfactant demonstrated signs of systemic neonatal infection or pneumonia in the first days of life (12). 
From in vitro studies, there is serious concern that surfactant administration might interfere with pulmonary defense mechanisms $(13,14)$. Based on animal studies (15), it has been speculated that surfactant treatment might actually promote bacterial growth in premature infants with GBS pneumonia. Using our new model, we investigated the effect of a modified porcine surfactant (Curosurf) on bacterial proliferation, inflammatory changes, and lung function in experimental neonatal GBS pneumonia.

\section{METHODS}

Bacteria. A capsulated GBS strain found to be pathogenic to rabbits was used for the present experiments. It is a GBS Ia 90 LD serologic subtype supplied by Stellan Håkansson, Department of Pediatrics, Umeå, Sweden.

On the day before the experiments, the strain, which was stored in aliquots at $-70^{\circ} \mathrm{C}$ until use, was inoculated into $3 \mathrm{~mL}$ of trypticase soy broth (TSB 3\%, Becton Dickinson, Cockeysville, MD) as an overnight starter culture. After a $12-\mathrm{h}$ incubation at $37^{\circ} \mathrm{C}, 0.3 \mathrm{~mL}$ of the suspension was inoculated into five separate tubes each containing $10 \mathrm{~mL}$ of fresh TSB $3 \%$ to shift bacterial growth to the "mid logarithmic growth phase" (16). The strain was then centrifuged at $900 \times g$ for $10 \mathrm{~min}$ at $4^{\circ} \mathrm{C}$, washed in saline, and resuspended in sterile $0.9 \% \mathrm{NaCl}$. The OD of the suspension was measured spectrophotometrically at $595 \mathrm{~nm}$ and adjusted to a value corresponding to $\sim 10^{9} \mathrm{CFU} / \mathrm{mL}$.

The exact number of viable $\mathrm{CFU} / \mathrm{mL}$ in the GBS suspension used for every individual experiment was determined by doing a serial dilution of the bacterial suspension in sterile saline. Aliquots $(100 \mu \mathrm{L})$ from the dilutions $10^{-5}$ to $10^{-10}$ were finally spread on blood agar plates $(5 \%$ sheep blood agar) and incubated for $24 \mathrm{~h}$ at $37^{\circ} \mathrm{C}$ in air with $5 \% \mathrm{CO}_{2}$ to promote growth. GBS growth was recognizable by $\beta$-hemolysis on the blood agar plate. The number of CFU was determined using an electric colony counter. Each step was carried out in duplicate, and the average result from the two plates was used for further calculation. Autoclaved materials were used for all above procedures.

Surfactant. Curosurf is a modified natural surfactant isolated from minced pig lungs by chloroform-methanol extraction and liquid-gel chromatography. It is suspended in saline at a concentration of $80 \mathrm{mg} / \mathrm{mL}$. This surfactant contains about $99 \%$ polar lipids (main component: dipalmitoylphosphatidylcholine) and $1 \%$ hydrophobic proteins (SP-B and SP-C) (17). The extraction procedure removes SP-A. To exclude bacterial contamination, Curosurf is sterilized using a high-pressure micropore filter system (first filter $1.0 \mu \mathrm{m}$, second filter $0.45 \mu \mathrm{m}$, and third filter $0.25 \mu \mathrm{m})$. The sterility of each batch is confirmed by bacteriologic examination of random vials. The physiologic effects of Curosurf have been confirmed in vitro, in animal experiments $(18,19)$, and in randomized clinical trials $(11,20)$. The standard dose used in these trials was $200 \mathrm{mg} / \mathrm{kg}$. The batch of surfactant used for the present experiments was tested in the pulsating bubble surfactometer. At a concentration of $5 \mathrm{mg} / \mathrm{mL}$, it reduced minimum surface tension to $2 \mathrm{mN} / \mathrm{m}$ during $50 \%$ cyclic film compression. Its physiologic activity was proven in experiments on ventilated immature rabbits delivered at a gestational age of $27 \mathrm{~d}(21)$.

Animals. New Zealand White rabbit fetuses were delivered by cesarean section at $29.5 \mathrm{~d}$ gestation (term $=31$ d). The animals were anesthetized, tracheotomized, and ventilated in individual boxes in a body plethysmograph system (21). Three $\mathrm{mL} / \mathrm{kg}$ pentobarbital (Mebumal Vet 6 $\mathrm{mg} / \mathrm{mL}$, Nordvacc, Skärholmen, Sweden) and $3 \mathrm{~mL} / \mathrm{kg}$ of the muscle relaxant pancuronium bromide (Pavulon 0.2 $\mathrm{mg} / \mathrm{mL}$, Organon, Göteborg, Sweden) were injected intraperitoneally every $2 \mathrm{~h}$ and additionally if needed. At 60 and $180 \mathrm{~min}$, 5\% glucose (Kabi Pharmacia, Stockholm, Sweden) was given intraperitoneally at a dose of 10 $\mathrm{mL} / \mathrm{kg}$. At the end of the ventilation period, the animals were killed by intracranial injection of $0.5 \mathrm{~mL}$ of lidocaine (Xylocaine $20 \mathrm{mg} / \mathrm{mL}$, Astra, Södertälje, Sweden). The abdomen was opened with sterile instruments, and the diaphragms were inspected for evidence of pneumothorax. Then the thorax was opened and heart blood was aspirated from the right ventricle for culturing of bacteria (Sigma Oxoid blood culture system, Unipath, Basingstoke, UK); in addition, a heparinized sample was taken for blood gas analysis (ABL, Radiometer, Copenhagen, Denmark).

Both lungs were then removed aseptically and weighed. The right lung was fixed for histologic examination. The left lung was used for quantification of bacterial growth $(22,23)$. After processing in a nylon microchamber tissue homogenizer (Sorvall Omnimix, Dupont Instruments, Newtown, CT), the lung homogenate was serially diluted and the number of CFU was calculated using blood agar plates by applying the same methodology as described above for determination of bacterial number in the GBS suspension. From the number of colonies detected and the dilution, we calculated the number of CFU per gram of lung tissue (wet weight). The design of the study corresponds to the Swedish animal protection law, and the trial was approved by the local committee for animal research.

Ventilator equipment and lung function measurements. The newborn animals were ventilated in warmed, sealed Plexiglas chambers as previously described (21). Up to 10 littermates were ventilated in parallel with a pressurecontrolled Servo 900 B ventilator (Siemens-Elema, Solna, Sweden) delivering $100 \% \mathrm{O}_{2}$ at a frequency of 40 $\min ^{-1}$, an inspiration time of $0.75 \mathrm{~s}$, and a working pressure of $50 \mathrm{~cm} \mathrm{H}_{2} \mathrm{O}$. The peak pressure for the animals in the different boxes was adjusted individually to maintain a tidal volume of $8-10 \mathrm{~mL} / \mathrm{kg}$ body weight (21). The insufflation pressure was recorded with a pressure transducer (EMT 34; Siemens-Elema). The tidal volume was measured with a modified "Fleisch-tube," a differential pressure transducer, an integrator, and an amplifier 
(EMT 31, EMT 32, EMT 41; Siemens-Elema). The compliance of the respiratory system was calculated for each individual time point by dividing the tidal volume adjusted for body weight by the corresponding peak pressure. No positive end-expiratory pressure was applied, because this could have masked differences in compliance due to variations in surfactant function (24). Recordings including an ECG from subcutaneous needles were taken at $15,30,45,60,90,120,150,180,210,240$, 270, and 300 min (Mingograf 81; Siemens-Elema). Animals with severe ECG abnormalities (bradycardia $<100$ $\min ^{-1}$, atrioventricular block) were excluded from the study.

In vitro studies of bacterial growth. In vitro growth of GBS was studied in the presence of different concentrations of surfactant. GBS $\left(10^{9} \mathrm{CFU}\right)$ were suspended in 5 $\mathrm{mL}$ of sterile normal saline. Aliquots of this suspension were serially diluted and spread on blood agar plates for counting of $\mathrm{CFU}$. After the bacterial suspension was incubated at $37^{\circ} \mathrm{C}$ for $4 \mathrm{~h}$ under agitation at $150 \mathrm{rpm}$ (Incubator Shaker G 25, New Brunswick Scientific, Edison, $\mathrm{NJ}$ ), another sample was processed as described above. The number of bacteria at time 0 was subtracted from that at $4 \mathrm{~h}$, and the results were expressed as mean $\log _{10}$ CFU. A positive log difference indicated proliferation of GBS, and a negative log difference indicated a decrease in the number of viable bacteria. Similar experiments were performed after addition of varying amounts of Curosurf to the suspension $(1,10$, and $20 \mathrm{mg} / \mathrm{mL}$ ). Three or four experiments were carried out with each surfactant concentration.

General design of the animal studies. All fetuses were first connected to the ventilator for $15 \mathrm{~min}$ to allow stabilization after delivery and tracheotomy. At $15 \mathrm{~min}$, the animals received via the tracheal cannula either saline or GBS suspension $(5 \mathrm{~mL} / \mathrm{kg})$. Animals were allocated at random to the following groups.

Growth controls. These animals received $5 \mathrm{~mL} / \mathrm{kg}$ GBS suspension at $15 \mathrm{~min}$. They were ventilated for only $1 \mathrm{~min}$ after GBS inoculation to remove the instilled fluid from the central airways to the periphery of the lungs. The counts from this group were used to check viability and distribution of the bacteria immediately after inoculation.

Group I (GBS-Curosurf). Animals in this group received $5 \mathrm{~mL} / \mathrm{kg}$ of the GBS suspension at $15 \mathrm{~min}$. After another $15 \mathrm{~min}, 2.5 \mathrm{~mL} / \mathrm{kg}$ of surfactant corresponding to 200 $\mathrm{mg} / \mathrm{kg}$ body weight was administered by intratracheal bolus injection. The animals were killed after a 5-h ventilation period, and bacterial proliferation in the lungs and heart blood was quantified as described above.

Group II (GBS-NaCl). These animals were inoculated with $5 \mathrm{~mL} / \mathrm{kg}$ GBS suspension at $15 \mathrm{~min}$ and received 2.5 $\mathrm{mL} / \mathrm{kg}$ of sterile $0.9 \% \mathrm{NaCl}$ at $30 \mathrm{~min}$ via the tracheal cannula. They were ventilated for $5 \mathrm{~h}$, and blood cultures and counting of bacteria in lung tissue were performed as described above.

Group III ( $\mathrm{NaCl}-\mathrm{NaCl})$. Animals in this "saline control" group received $5 \mathrm{~mL} / \mathrm{kg}$ of sterile $0.9 \% \mathrm{NaCl}$ at $15 \mathrm{~min}$ and $2.5 \mathrm{~mL} / \mathrm{kg}$ of $\mathrm{NaCl}$ at $30 \mathrm{~min}$ to check the influence of the intratracheal fluid load on lung function. Bacteriologic examination was performed in the same way as in the other groups to exclude contamination with GBS or other pathogens.

Histology. The lungs were fixed in $4 \%$ formaldehyde and embedded in paraffin. Longitudinal sections were cut from the middle of each paraffin block in a standardized fashion. The sections were stained with hematoxylin and eosin or with Gram's stain and examined under a light microscope with particular reference to inflammatory changes and presence of bacteria in the air spaces. The proportion (percentage) of total lung parenchyma with pneumonia, as indicated by the presence of inflammatory cells in the terminal air spaces, was estimated using a four-degree scale: $0,<10 \%, 10-30 \%$, and $>30 \%$. The histologic evaluation was performed blindly, i.e. without knowledge of the experimental condition of individual animals.

Statistics. All data are expressed as means $\pm \mathrm{SD}$. Because bacterial growth follows a logarithmic curve (16), all figures for bacterial proliferation were transformed into decimal logarithms $\left(\log _{10}\right)$. The CRISP statistical program (Crunch Software, San Francisco, CA) was used for data analysis. Between-group differences were calculated by analysis of variance followed by StudentNewman-Keuls' test. Differences in in vitro bacterial proliferation were evaluated with $t$ test. Pearson's correlation and $\chi^{2}$ test were used when appropriate. A $p$ value $<0.05$ was regarded as statistically significant.

\section{RESULTS}

In vitro growth of streptococci. The number of viable GBS in saline remained virtually unchanged over a 4-h period of observation (log difference +0.01 ). At Curosurf concentrations of 1 or $10 \mathrm{mg} / \mathrm{mL}$, there was a slight reduction in bacterial growth (log difference -0.18 and -0.48 , respectively). After addition of Curosurf at a concentration of $20 \mathrm{mg} / \mathrm{mL}$, a significant decrease in bacterial number was observed (log difference -2.47 compared with time $0 ; p<0.05$ ).

Animal studies. Fifty-four liveborn fetuses from 10 litters were used for the experiments. Four animals (two in group I, one in group II, one in group III) died before the end of the experiment or had severe ECG abnormalities. One of these animals had pneumothorax. One animal in the growth control group was excluded because the blood culture showed growth of Staphylococcus epidermidis indicating contamination. Thus, 49 animals were available for final data analysis.

Growth controls. Mean birth weight of these 12 animals was $41.7 \pm 9.2 \mathrm{~g}$, i.e. similar to that of the other experimental groups (Table 1). The number of CFU (mean $\log _{10}$ $\pm \mathrm{SD}$ ) per gram lung weight was $8.13 \pm 0.54$. None of the blood cultures in this group were GBS positive.

Figure 1 shows the correlation between the number of bacteria given to each growth control rabbit and the 
Table 1. Characterization of animals in different treatment groups*

\begin{tabular}{|c|c|c|c|}
\hline Parameters & $\begin{array}{l}\text { Group I: } \\
\text { GBS-Curosurf } \\
(n=12)\end{array}$ & $\begin{array}{l}\text { Group II: } \\
\text { GBS-NaCl } \\
(n=13)\end{array}$ & $\begin{array}{c}\text { Group III: } \\
\text { NaCl-NaCl } \\
(n=12)\end{array}$ \\
\hline Birth weight $(\mathrm{g})$ & $40.4 \pm 6.7$ & $38.2 \pm 5.8$ & $40.6 \pm 6.0$ \\
\hline $\begin{array}{l}\text { Heart rate at } 300 \mathrm{~min} \\
\left(\mathrm{~min}^{-1}\right)\end{array}$ & $234 \pm 38$ & $220 \pm 37$ & $244 \pm 41$ \\
\hline Final $\mathrm{pH}$ & $7.31 \pm 0.12$ & $7.32 \pm 0.11$ & $7.32 \pm 0.12$ \\
\hline Final $\mathrm{PCO}_{2}(\mathrm{kPa})$ & $4.57 \pm 0.74$ & $3.96 \pm 0.81$ & $5.18 \pm 1.78$ \\
\hline $\begin{array}{l}\text { GBS-positive blood } \\
\text { culture }\end{array}$ & $\begin{array}{l}11 / 12 \\
(92 \%)\end{array}$ & $\begin{array}{l}13 / 13 \\
(100 \%)\end{array}$ & $\begin{array}{l}0 / 12 \\
(0 \%)\end{array}$ \\
\hline Left lung weight (g) & $0.42 \pm 0.11$ & $0.37 \pm 0.11$ & $0.42 \pm 0.10$ \\
\hline
\end{tabular}

*Values are given as means \pm SD or ratios.

number of CFU detected in the left lung of the same animal after $1 \mathrm{~min}$ of ventilation. Although in individual animals maldistribution to either the right or the left lung seems to have occurred, it is justifiable to assume that approximately half of the instilled bacteria was distributed to each lung.

Animals subjected to prolonged ventilation (groups I-III). All these animals were ventilated for $5 \mathrm{~h}$. Birth weights were nearly identical in the three groups (Table 1). Physiologic data at the end of the experiment including heart rate, blood gas values, and weight of the left lung were also similar (Table 1).

Bacterial proliferation. The number of GBS instilled into the airways was nearly identical in all infected groups (growth controls: $8.15 \pm 0.52$; GBS-Curosurf: $8.12 \pm$ 0.62 ; GBS-NaCl: $8.14 \pm 0.54$ ). At the end of the 5-h period of ventilation, significant bacterial proliferation had occurred in both group I (GBS-Curosurf) and group II (GBS-NaCl) animals (Fig. 2). However, this proliferation was less marked in surfactant-treated rabbit neonates than in animals receiving saline $(8.96 \pm 0.38$ versus

Crv $\cdot 10^{8}$ /lung

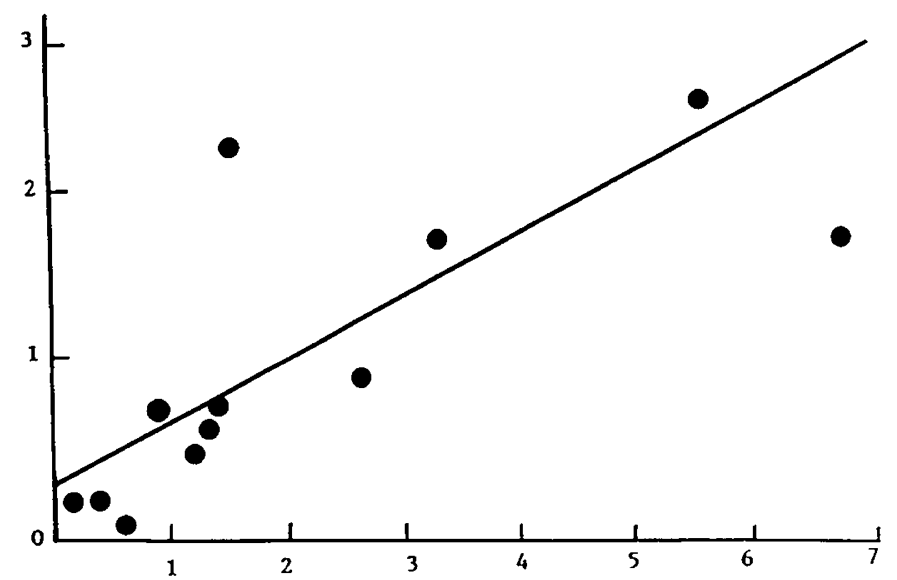

CFU $\cdot 10^{8} /$ rabbit

Figure 1. Correlation between the number of CFU injected intratracheally and the actual number of CFU detected in the left lung of growth control animals killed $1 \mathrm{~min}$ after inoculation. $r=0.72, p<0.01$; $\mathrm{y}=0.39+0.31 \mathrm{x}$

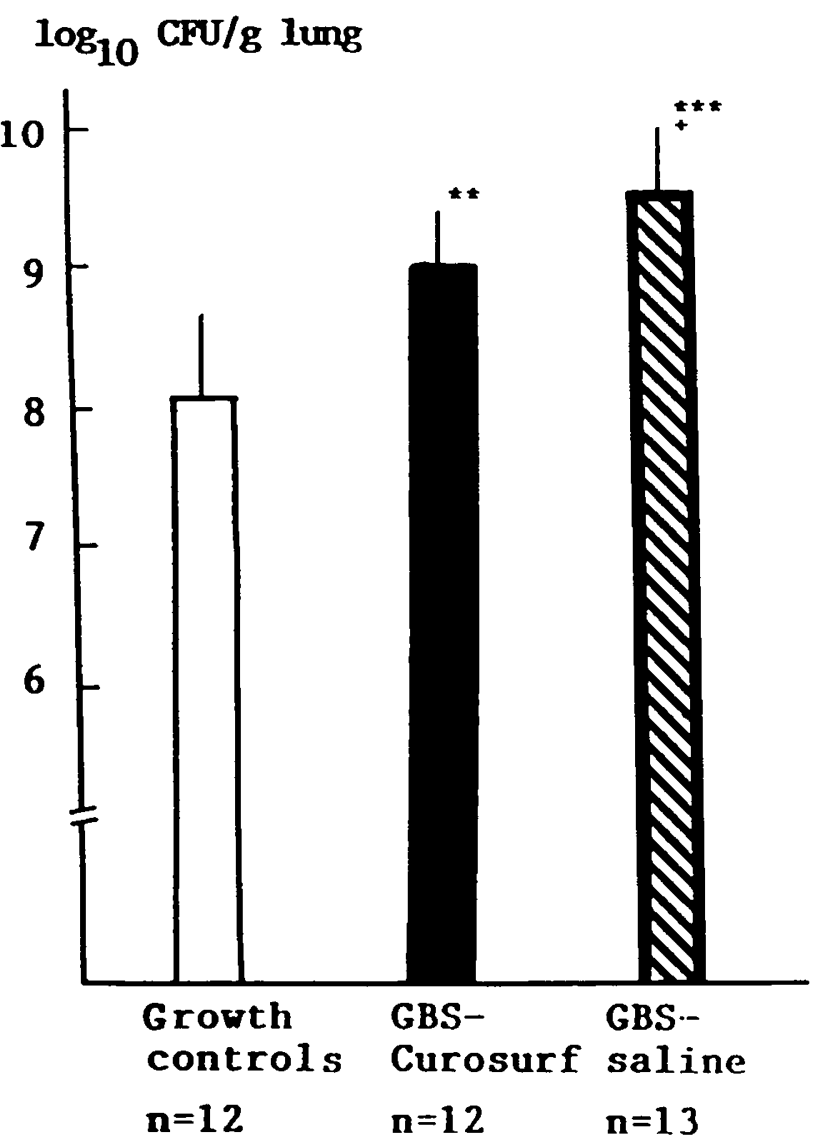

Figure 2. Number of bacteria $\left(\log _{10} \mathrm{CFU} / \mathrm{g}\right.$ lung tissue; mean $\left.\pm \mathrm{SD}\right)$ isolated from the left lung of rabbits after $5 \mathrm{~h}$ of ventilation in the two treatment groups in comparison with growth controls. ${ }^{* * *}, p<0.001$ vs growth controls; ${ }^{* *}, p<0.01$ vs growth controls;,$+ p<0.05$ vs GBS-Curosurf.

$9.46 \pm 0.50 ; p<0.05)$. Assuming that half of the instilled bacteria reached the left lung, there was nearly a 10 -fold increase in bacterial number in the Curosurf-treated and an approximately 40 -fold increase in the number of CFU in saline-treated, GBS-infected animals. None of the rabbits in group III ( $\mathrm{NaCl}-\mathrm{NaCl})$ showed bacterial growth in lung homogenate.

All blood cultures in the saline control group (group III) were sterile, whereas 24 of 25 GBS-infected rabbits showed GBS-positive blood cultures at the end of the experiment (Table 1).

Lung function. Average initial lung-thorax compliance values were compatible with lung maturity (21), but there was considerable individual variation as indicated by large SD (Table 2).

All animals showed a decrease in compliance after intratracheal instillation of $5 \mathrm{~mL} / \mathrm{kg}$ of fluid at $15 \mathrm{~min}$, irrespective of whether GBS or $\mathrm{NaCl}$ was administered. Instillation of $2.5 \mathrm{~mL} / \mathrm{kg}$ surfactant or $\mathrm{NaCl}$ at $30 \mathrm{~min}$ did not result in any significant additional change in compliance. Animals receiving only saline at 15 and $30 \mathrm{~min}$ tended to have lower compliance values throughout the experiment. At some individual time points, this difference reached the 5\% level of statistical significance because SD were small in the saline control group. During 
Table 2. Lung-thorax compliance at different time intervals in various groups of animals*

\begin{tabular}{cccc}
\hline & \multicolumn{3}{c}{ Compliance $\left(\mathrm{mL} \cdot \mathrm{cm} \mathrm{H}_{2} \mathrm{O}^{-1} \cdot \mathrm{kg}^{-1}\right)$} \\
\cline { 2 - 4 } Time & Group I: & Group II: & Group III: \\
(min) & $(n=12)$ & $\begin{array}{c}\text { GBS-NaCl } \\
(n=13)\end{array}$ & $\begin{array}{c}\mathrm{NaCl}-\mathrm{NaCl} \\
(n=12)\end{array}$ \\
\hline $15 \dagger$ & $0.78 \pm 0.22$ & $0.91 \pm 0.33$ & $0.74 \pm 0.15$ \\
$30 \neq$ & $0.59 \pm 0.13$ & $0.74 \pm 0.22$ & $0.55 \pm 0.22$ \\
45 & $0.63 \pm 0.10$ & $0.73 \pm 0.18$ & $0.57 \pm 0.09 \S$ \\
60 & $0.64 \pm 0.08$ & $0.65 \pm 0.08$ & $0.57 \pm 0.06 \S \|$ \\
120 & $0.68 \pm 0.12$ & $0.67 \pm 0.11$ & $0.56 \pm 0.07 \S \|$ \\
180 & $0.66 \pm 0.18$ & $0.75 \pm 0.16$ & $0.59 \pm 0.11 \S$ \\
240 & $0.63 \pm 0.09$ & $0.63 \pm 0.07$ & $0.58 \pm 0.09$ \\
300 & $0.61 \pm 0.09$ & $0.63 \pm 0.11$ & $0.56 \pm 0.09$ \\
\hline
\end{tabular}

${ }^{*}$ All values are given as means $\pm \mathrm{SD}$.

$\nmid$ Before instillation of GBS suspension or $0.9 \% \mathrm{NaCl}$. $\ddagger$ Before instillation of Curosurf or $0.9 \% \mathrm{NaCl}$. $\S p<0.05 v s$ group II.

$\| p<0.05 v s$ group I.

the 5-h period of ventilation, mean lung-thorax compliance values decreased by $22 \%$ in group I (GBS-Curosurf), by $31 \%$ in group II (GBS-NaCl), and by $24 \%$ in group III $(\mathrm{NaCl}-\mathrm{NaCl})$. There were no statistically significant differences between the groups at the end of the experiment.

Histologic evaluation. Lungs from animals in the growth control group had no evidence of inflammation, but small

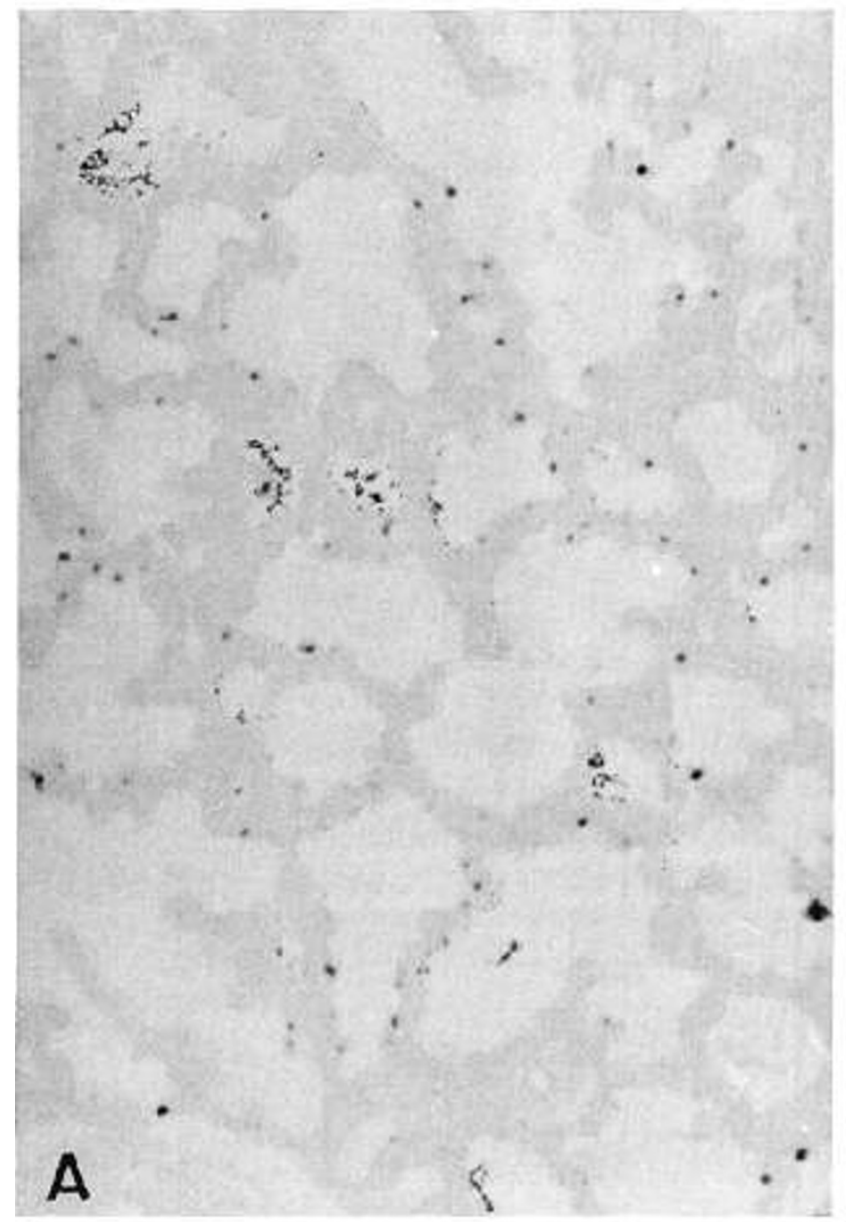

groups of Gram-positive cocci could be identified in terminal air spaces (Fig. 3A). Bacterial proliferation was a prominent feature in Gram-stained sections from groups I and II (Fig. $3 B$ ) after $5 \mathrm{~h}$ of ventilation.

Inflammatory changes characterized by intraalveolar accumulation of neutrophils and, to a lesser extent, macrophages were found in one of the 12 ventilated animals receiving only saline (group III) and in 22 of the 25 animals that were inoculated with GBS and ventilated for $5 \mathrm{~h}$ (groups I and II) $(p<0.001)$. In two surfactant-treated and one saline-treated, GBS-infected rabbit neonate, lung sections showed no evidence of pneumonia (Table 3). When present, the inflammatory changes (Fig. 4) were most prominent in the peripheral parts of the lungs and tended to be more severe in GBS-infected rabbits treated with saline, involving $>30 \%$ of the parenchyma in seven animals (Table 3). A corresponding degree of inflammation was noted in only one of the infected animals treated with surfactant. However, this difference did not reach the limit level of statistical significance $\left(\chi^{2}\right.$ test).

\section{DISCUSSION}

Surfactant is an important component of the pulmonary defense system (25), and the effects of bronchoal-

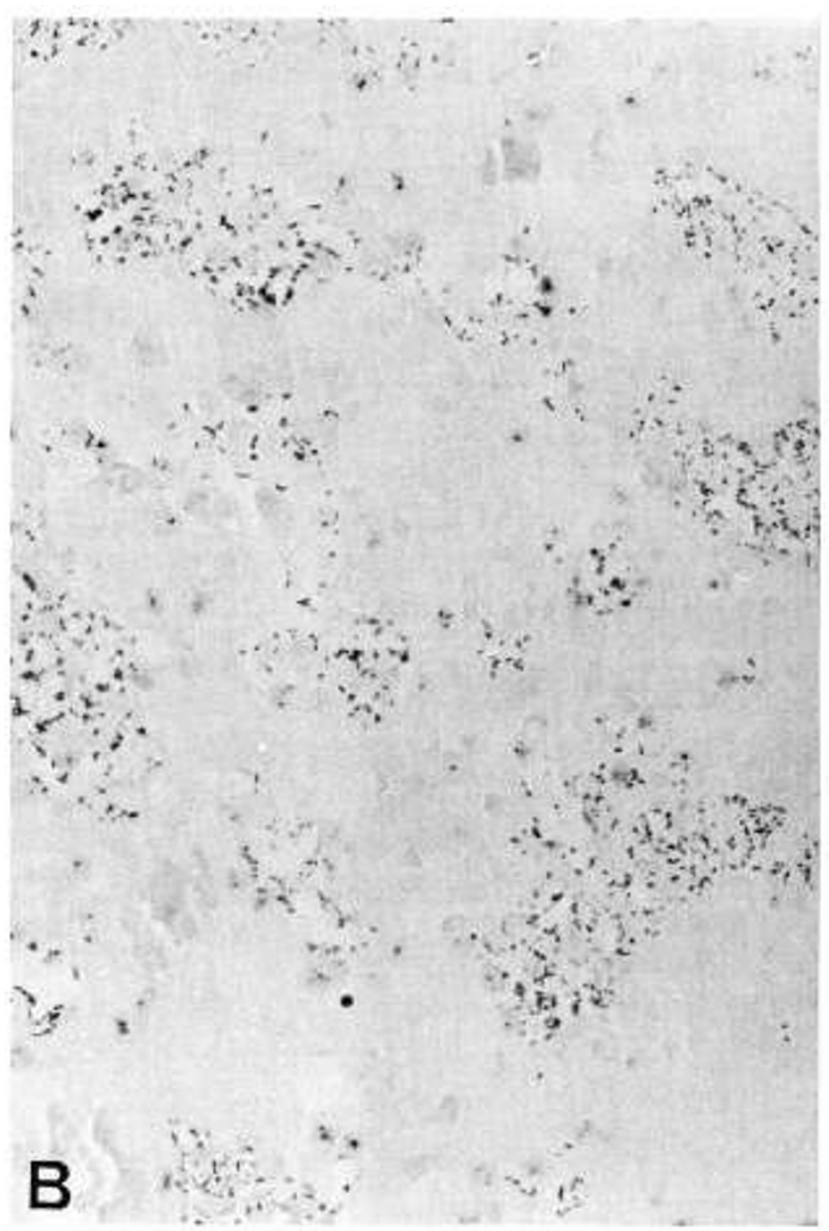

Figure 3. Gram-positive cocci in alveolar spaces. Gram's stain $\times 250$. $A$, Growth control animal killed 1 min after GBS inoculation. $B$, Prominent bacterial proliferation in the lung of a GBS-infected animal treated with saline (group II) and ventilated for 5 h. 
Table 3. Histologic grading of pulmonary inflammatory changes in rabbits of different treatment groups and in growth control animals

\begin{tabular}{ccccc}
\hline $\begin{array}{c}\text { Percent of } \\
\text { parenchyma } \\
\text { involved }\end{array}$ & $\begin{array}{c}\text { Group I: } \\
\text { GBS-Curosurf } \\
(n=12)\end{array}$ & $\begin{array}{c}\text { Group II: } \\
\text { GBS-NaCl } \\
(n=13)\end{array}$ & $\begin{array}{c}\text { Group III: } \\
\text { NaCl-NaCl } \\
(n=12)\end{array}$ & $\begin{array}{c}\text { Growth } \\
\text { controls } \\
(n=12)\end{array}$ \\
\hline 0 & 2 & 1 & 11 & 12 \\
$<10$ & 4 & 3 & 1 & 0 \\
$10-30$ & 5 & 2 & 0 & 0 \\
$>30$ & 1 & 7 & 0 & 0 \\
\hline
\end{tabular}

veolar fluid and its cellular components on bacterial growth have been documented in several studies (25-28). Surfactant also stabilizes alveoli and small airways, preventing atelectasis (21), epithelial disruption (29), and protein leakage $(30,31)$ in the lungs of ventilated, premature animals. The formation of a surfactant monolayer on the alveolar surface probably contributes to antibacterial defense by acting as a mechanical barrier facilitating mucociliary clearance of inhaled particles.

Our present in vitro data indicate a significant negative impact of Curosurf on bacterial growth at a concentration of $20 \mathrm{mg} / \mathrm{mL}$. This is $6-7$ times higher than the "critical concentration" of surfactant phospholipids in the fetal lung fluid at birth but less than one fifth of the estimated phospholipid concentration of the alveolar lining layer in

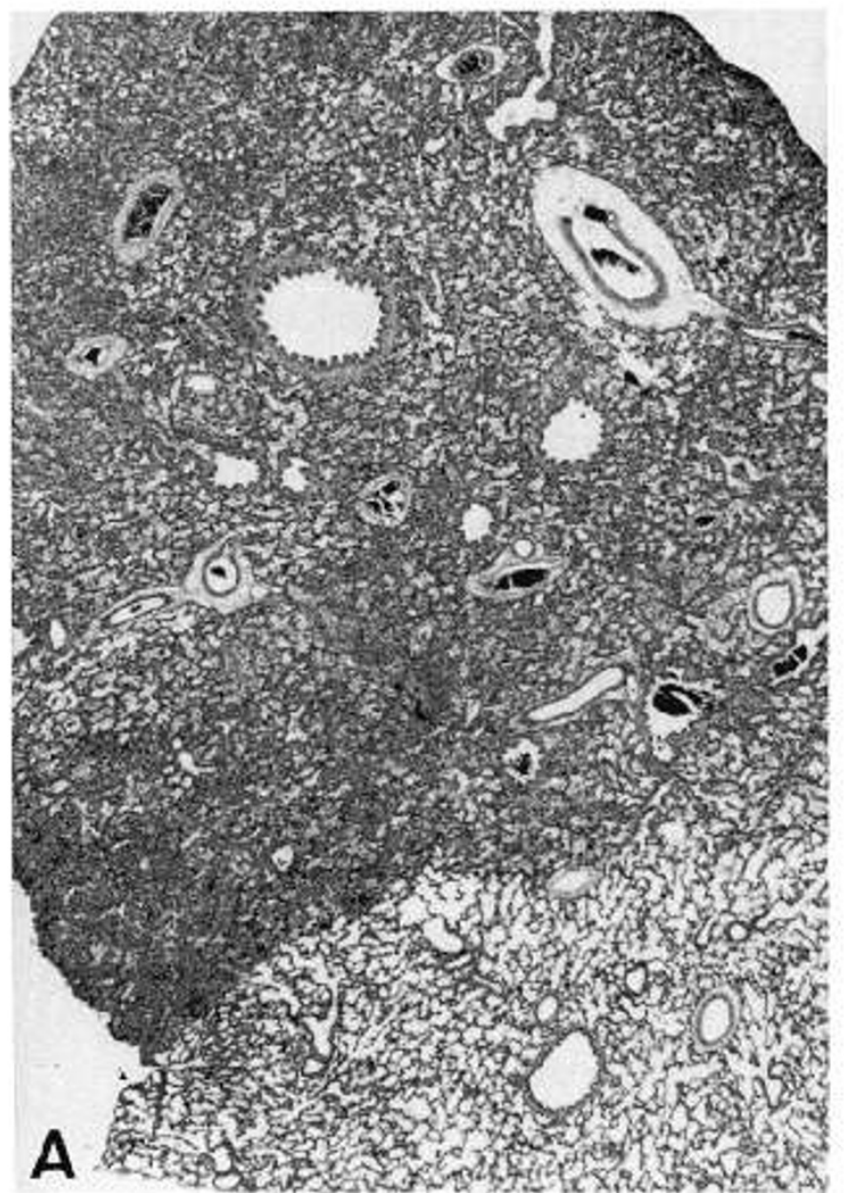

adult animals (32). The phospholipid concentration of airway fluid resulting from instillation of $200 \mathrm{mg} / \mathrm{kg}$ surfactant lipids in a near-term animal 30 min after birth can be calculated only roughly. At birth, the volume of fetal lung fluid is about $30 \mathrm{~mL} / \mathrm{kg}$ and the pool size of endogenous surfactant about $20 \mathrm{mg} / \mathrm{kg}$ (33); this corresponds to a concentration of $0.6-1 \mathrm{mg} / \mathrm{mL}$. The concentration of endogenous surfactant in the airway fluid probably increases rapidly during the first few hours after birth due to accelerated release of lamellar bodies from type II cells and a concomitant resorption of fetal lung water. In our experimental animals, an additional amount of exogenous surfactant, about 10 times larger than the pool size of endogenous surfactant at birth, was administered after a period of artificial ventilation. This dose was probably not distributed homogeneously in the lungs, and the final concentration of surfactant must therefore be subject to considerable regional variation. Nevertheless, it seems likely that in many air spaces of the GBS-infected animals treated with Curosurf the concentration of surfactant in the airway fluid amounted to a level equivalent to that causing inhibition of bacterial growth in vitro. Thus, it is possible that the reduced proliferation of GBS in these animals was, at least in part, a direct effect of surfactant on the microorganisms, not mediated by phagocytic cells.

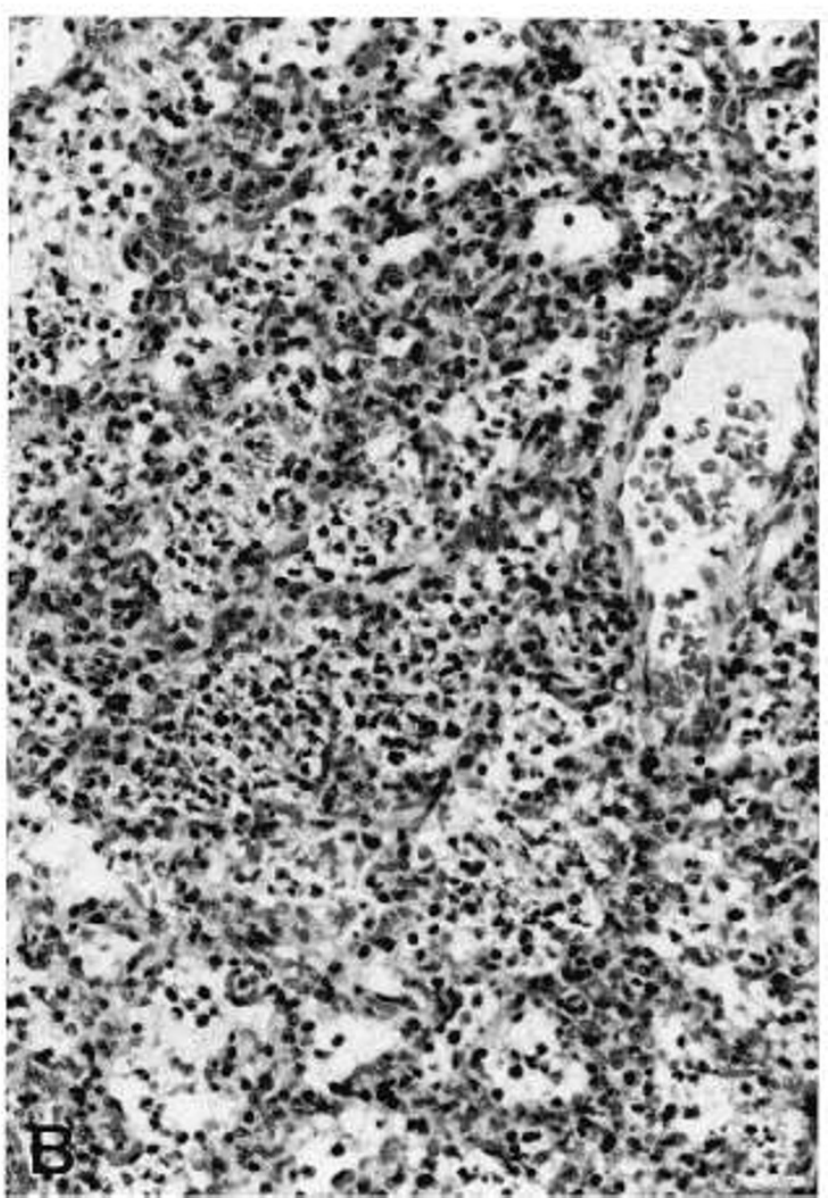

Figure 4. Histologic findings in a GBS-inoculated animal treated with saline (group II) and ventilated for 5 h. Hematoxylin and eosin. $A$, Widespread pneumonia involving more than $30 \%$ of total lung parenchyma. $\times 25 . B$, Detail from the same section showing prominent intraalveolar accumulation of inflammatory cells, mainly neutrophils. $\times 250$. 
Theoretically, treatment with surfactant could have also improved clearance of bacteria from the air spaces by counterbalancing the inhibitory effects of serum proteins leaking into the air spaces with the inflammatory exudate. Keeping the alveoli open throughout the ventilatory cycle facilitates surface flux from the alveoli to the mucociliary escalator and probably prevents local hypoxia and ischemia, which could interfere with phagocyte function. Total lung volumes were not measured in the present experiments, only tidal volumes. We therefore cannot draw any conclusions in regard to the possible recruitment of alveolar spaces in surfactant-treated animals. Lung-thorax compliance measurements indicated no significant differences between surfactant-treated animals and controls, and the absolute values for compliance were of the same order as those previously recorded with similar methods in healthy near-term animals (21). The exact mechanisms by which surfactant reduced bacterial growth in the present animal experiments thus remain to be clarified.

Pilot studies of surfactant treatment in neonates with severe respiratory failure due to pneumonia indicate that this therapy might be beneficial (34-37), although the therapeutic response (improvement in oxygenation) is slower than in infants with "idiopathic" RDS. So far, controlled trials of surfactant treatment for neonatal pneumonia have not been reported.

The surfactant used in our study lacks the hydrophilic surfactant proteins SP-A and SP-D. Both of these proteins are important stimulants of macrophage function $(38,39)$. In addition, SP-A plays a key role in regulating surfactant secretion and recycling (40), and it increases resistance to inhibition by serum proteins. Currently available surfactant preparations lacking SP-A and SP-D might therefore be suboptimal for treating infants with respiratory failure due to pneumonia. A decreased phagocytic capacity and a decreased release of cytokines such as tumor necrosis factor and IL-1 have been observed after in vitro exposure of phagocytic cells to different doses of Curosurf, suggesting that this surfactant might in fact down-regulate inflammatory reactions in the lung $(13,14)$.

A direct comparison of our results with data published in the literature is not possible, because different GBS strains at different infecting doses have been used. The serologic subtype Ia used for our studies and by other investigators $(7,8,41)$ was isolated from neonates with GBS pneumonia and early onset septicemia, whereas type III GBS used by Hall and Sherman (42) is more commonly found in neonates beyond the first days of life (often in combination with meningitis). In addition, various surfactants seem to have different effects on bacterial growth (41), and fetuses of different gestational ages show distinct differences in their capacity to kill streptococci. Hall and Sherman (42) reported that mature rabbits were capable of reducing the number of inhaled GBS over an 8-h period of observation, whereas a significant increase in bacterial number was found in immature an- imals. In these studies, GBS was administered as an aerosol, using specially designed cages by which a similar number of bacteria could be given simultaneously to many rabbits. However, in contrast to the present experiments in which the approximate number of instilled bacteria was known, the number of inhaled aerosolized bacteria had to be judged by counting the bacteria in the lungs of rabbits killed immediately after exposure to GBS $(41,42)$. In addition, the number of bacteria applied to the lungs in the aerosol studies $(41,42)$ was less than the number of GBS administered in our model.

Tracheotomy, needed for ventilation and for lung function measurements in our study, bypasses the upper airways and interferes with mucociliary clearance and may therefore be considered an additional factor promoting bacterial growth. Mechanical ventilation with intermittent positive airway pressure and high $\mathrm{O}_{2}$ levels might also interfere with the pulmonary defense system and cause a more rapid proliferation of bacteria (43). Nearterm rabbit fetuses born by cesarean section show a decreased capacity to kill invading microorganisms in comparison to animals that are born spontaneously, probably reflecting a delayed influx of phagocytes into the bronchoalveolar space (44). These circumstances might to some extent explain why we, in contrast to other investigators (42), could observe proliferation of GBS in near-term rabbits.

In our opinion, intratracheal injection of a liquid bolus mimics an ascending infection in utero more closely than does infection with aerosolized bacteria. Furthermore, the fetuses in our experimental setup were paralyzed and kept in a supine position, which might enhance bacterial growth in comparison with animals breathing spontaneously in an aerosolization chamber. With certain limitations (45), it could be argued that conditions similar to our experimental design exist in critically ill, immobilized, ventilated neonates with GBS pneumonia.

The model described in the present paper should allow further investigation of cellular and humoral factors determining bacterial proliferation and inflammatory response in neonatal GBS pneumonia and septicemia, also in more immature ventilated animals. We conclude that treatment of ventilated, near-term newborn rabbits with a modified porcine surfactant mitigated bacterial proliferation in experimental GBS pneumonia.

Acknowledgments. The authors thank Bim Linderholm, Eva Lundberg, and Petru Popa for skillful technical assistance.

\section{REFERENCES}

1. Jelinkova J 1977 Group B streptococci in the human population. Curr Top Microbiol Immunol 76:126-165

2. Committee on Infectious Diseases and Committee on Fetus and Newborn 1992 Guidelines for prevention of group B streptococcal (GBS) infection by chemoprophylaxis. Pediatrics 90:775-778

3. Shigeoka AO, Hall RT, Hemming VG, Allred CD, Hill HR 1978 Role of antibody and complement in opsonization of group B streptococci. Infect Immun 21:34-40 
4. Baker CJ, Edwards MS, Kasper DL 1981 Role of antibody to native type III polysaccharide of group B streptococcus in infant infection. Pediatrics 68:544-549

5. Sherman MP, Ganz T 1992 Host defense in pulmonary alveoli. Annu Rev Physiol 54:331-350

6. Håkansson S, Bergholm AM, Holm SE, Wagner B, Wagner M 1988 Properties of high and low density subpopulations of group B streptococci: enhanced virulence of the low density variant. Microb Pathog 5:345-355

7. Wennerstrom DE, Schutt RW 1978 Adult mice as a model for early onset group B streptococcal disease. Infect Immun 19:741-744

8. Sherman MP, Goldstein E, Lippert T, Wennberg R 1982 Group B streptococcal lung infections in neonatal rabbits. Pediatr Res 16:209-212

9. Martin TR, Rubens CE, Wilson CB 1987 Lung antibacterial defense mechanisms in infant and adult rats: implications for the pathogenesis of group B streptococcal infections in the neonatal lung. $J$ Infect Dis 157:91-100

10. Ablow RC, Driscoll SG, Effmann EL, Gross I, Jolles CJ, Uauy R, Warshaw JL 1976 A comparison of early onset group B streptococcal neonatal infection and the respiratory distress syndrome. N Engl J Med 294:65-70

11. Speer CP, Robertson B, Curstedt T, Halliday HL, Compagnone D, Gefeller O, Herting E, Harms K, McClure G, Reid M, Tubman R, Herin P, Noack G, Kok J, Koppe J, van Sonderen L, Laufkötter E, Köhler W, Boenisch H, Albrecht K, Hanssler L, Haim M, Oetomo SB, Okken A, Altfeld PC, Groneck P, Kachel W, Relier JP, Walti H 1992 Randomized European multicenter trial of surfactant replacement therapy for severe neonatal respiratory distress syndrome: single versus multiple doses of Curosurf. Pediatrics $89: 13-20$

12. Herting E, Harms $\mathrm{K}$, Speer $\mathrm{CP}$, and members of the Collaborative European Multicenter Study Group 1991 Incidence of neonatal infections in very low birth weight infants with severe RDS treated with a natural porcine surfactant. Biol Neonate 59:382-383(abstr)

13. Speer CP, Götze B, Curstedt T, Robertson B 1991 Phagocytic function and TNF secretion of human monocytes exposed to natural porcine surfactant (Curosurf). Pediatr Res 30:69-74

14. Jarstrand C, Wiernik A, Curstedt T, Sundqvist KG 1991 Lung surfactant inhibits the lipopolysaccharide induced release of oxygen radicals, enzymes and interleukin-1 from phagocytes. Immun Infect Dis 1:179-182

15. Sherman M, D'Ambola J, Aeberhard E, Barrett CT 1988 Surfactant therapy of newborn rabbits impairs lung macrophage bactericidal activity. J Appl Physiol 65:137-145

16. Wilson GS, Miles AA, Parker MT 1983 Topley and Wilson's Principles of Bacteriology, Virology and Immunity. Vol I. Edward Arnold Publishers, London, pp 58-61

17. Curstedt T, Johansson J, Robertson B, Persson P, Löwenadler B, Jörnvall H 1993 Structure and function of hydrophobic surfactant-associated proteins. In: Bevilacqua G, Parmigiani S, Robertson B (eds) Surfactant in Clinical Practice. Harwood Academic Publishers, Chur, Switzerland, pp 55-60

18. Noack G, Berggren P, Curstedt T, Grossmann G, Herin P, Mortensson W, Nilsson R, Robertson B 1987 Severe neonatal respiratory distress syndrome treated with the isolated phospholipid fraction of natural surfactant. Acta Paediatr Scand 76:697-705

19. Robertson B, Curstedt T, Johansson J, Jörnvall H, Kobayashi T 1990 Structural and functional characterization of porcine surfactant isolated by liquidgel chromatography. In: von Wichert P, Müller B (eds) Basic Research on Lung Surfactant. Progress in Respiration Research, Vol 25. Karger, Basel, Switzerland, pp 237-246

20. Collaborative European Multicenter Study Group 1988 Surfactant replacement therapy for severe neonatal respiratory distress syndrome: an international randomized clinical trial. Pediatrics 82:683-691

21. Sun B, Kobayashi T, Curstedt T, Grossmann G, Robertson B 1991 Application of a new ventilator-multi-plethysmograph system for testing efficacy of surfactant replacement in newborn rabbits. Eur Respir J 4:364-370

22. Ruppert D, Jakab GJ, Sylwester DL, Grenn GM 1976 Sources of variance in the measurement of intrapulmonary killing of bacteria. $\mathrm{J}$ Lab Clin Med 87:544-558

23. Baron EJ, Finegold SM 1990 Bailey's and Scott's Diagnostic Microbiology. 8th Ed. CV Mosby, St. Louis, pp 297-298

24. Rider ED, Jobe AH, Ikegami M, Sun B 1992 Different ventilation strategies alter surfactant responses in preterm rabbits. J Appl Physiol 73:2089-2096
25. Van Iwaarden JF 1993 Surfactant and the pulmonary defense system. In: Robertson B, Van Golde LMG, Batenburg JJ (eds) Pulmonary Surfactant. From Molecular Biology to Clinical Practice. Elsevier, Amsterdam, pp 215225

26. LaForce FM 1976 Effect of alveolar lining material on phagocytic and bactericidal activity of lung macrophages against Staphylococcus aureus. J Lab Clin Med 88:691-699

27. O'Neill SJ, Lesperance E, Klass DJ 1984 Human lung lavage surfactant enhances staphylococcal phagocytosis by alveolar macrophages. Am Rev Respir Dis 130:1177-1179

28. Jonsson S, Musher DM, Goree A, Lawrence EC 1986 Human alveolar lining material and antibacterial defense. Am Rev Respir Dis 133:136-140

29. Grossmann G, Nilsson R, Robertson B 1986 Scanning electron microscopy of epithelial lesions induced by artificial ventilation in the immature neonatal lung: the prophylactic effect of surfactant replacement. Eur J Pediatr 145:361367

30. Robertson B, Berry D, Curstedt T, Grossmann G, Ikegami M, Jacobs H, Jobe A 1985 Leakage of protein in the immature rabbit lungs: effects of surfactant replacement. Respir Physiol 61:265-276

31. Ikegami M, Jobe AH, Tabor BL, Rider ED, Lewis JF 1992 Lung albumin recovery in surfactant-treated preterm ventilated lambs. Am Rev Respir Dis 145:1005-1008

32. Kobayashi T, Shido A, Nitta K, Inui S, Ganzuka M, Robertson B 1990 The critical concentration of surfactant in fetal lung liquid at birth. Respir Physiol 80:181-192

33. Stevens PA, Wright JR, Clements JA 1987 Changes in quantity, composition, and surface activity of alveolar surfactant at birth. J Appl Physiol 63:10491057

34. Lotze A, Knight GR, Martin GR, Bulas DI, Hull WM, O'Donnell RM, Whitsett JA, Short BL 1993 Improved pulmonary outcome after exogenous surfactant therapy for respiratory failure in term infants requiring extracorporeal membrane oxygenation. J Pediatr 122:261-268

35. Auten RL, Notter RH, Kendig JW, Davis JM, Shapiro DL 1991 Surfactant treatment of full-term newborns with respiratory failure. Pediatrics 87:101107

36. Gortner L, Pohlandt F, Bartmann P 1990 Wirkung eines bovinen Surfactants bei sehr kleinen Frühgeborenen mit konnataler Pneumonie. Monatsschr Kinderheilkd 138:274-278

37. Brehmer U, Jorch G 1993 Surfactanttherapie bei 41 Frühgeborenen < 34 SSW mit Verdacht auf konnatale Infektion (Fallkontrollanalyse). Klin Padiatr 205:78-82

38. Van Iwaarden F, Welmers B, Verhoef J, Haagsman HP, van Golde LMG 1990 Pulmonary surfactant protein A enhances the host-defense mechanism of rat alveolar macrophages. Am J Respir Cell Mol Biol 2:91-98

39. Van Iwaarden JF, Shimizu H, van Golde PHM, Voelker DR, van Golde LMG 1992 Rat surfactant protein $\mathrm{D}$ enhances the production of oxygen radicals by rat alveolar macrophages. Biochem J 286:5-8

40. Jobe AH, Rider ED 1992 Catabolism and recycling of surfactant. In: Robertson B, van Golde LMG, Batenburg JJ (eds) Pulmonary Surfactant. From Molecular Biology to Clinical Practice. Elsevier, Amsterdam, pp 313-337

41. Sherman MP, Campbell LA, Merritt TA, Shapiro DL, Long WA, Gunkel HJ 1990 The infected preterm rabbit lung. A model to test the effect of surfactant replacement on lung host defenses. In: von Wicherst, Müller B (eds) Basic Research on Lung Surfactant. Progress in Respiratory Research, Vol 25. Karger, Basel, Switzerland, pp 204-208

42. Hall SL, Sherman MP 1992 Intrapulmonary bacterial clearance of type III group B streptococcus is reduced in preterm compared with term rabbits and occurs independent of antibody. Am Rev Respir Dis 145:1172-1177

43. Sherman MP, Condiotti R 1987 Hyperoxia damages phagocytic defenses of the neonatal rabbit lung. J Appl Physiol 62:684-690

44. Zeligs BJ, Nerurkar LS, Bellanti JA, Zeligs JD 1977 Maturation of the rabbit alveolar macrophage during animal development. I. Perinatal influx into alveoli and ultrastructural differentiation. Pediatr Res 11:197-208

45. Nguyen BY, Peterson PK, Verbrugh HA, Quie PG, Hoidal HR 1983 Differences in phagocytosis and killing by alveolar macrophages from humans, rabbits, rats and hamsters. Infect Immun 36:504-509 